\title{
Stretch Injuries of Skeletal Muscles: Experimental Study in Rats' Soleus Muscle
}

\author{
Lesión por Estiramiento de los Músculos Esqueléticos: \\ Estudio Experimental con el Músculo Soleus de Ratas
}

"Célia Aparecida Stellutti Pachioni; **Nilton Mazzer; ${ }^{* *}$ Claudio Henrique Barbieri; "Marcela Regina de Camargo; "Cristina Elena Prado Teles Fregonesi; *Edna Maria do Carmo; *Andrea Jeanne Lourenço Nozabielli \& *Alessandra Rezende Martinelli

PACHIONI, S. C. A.; MAZZER, N.; BARBIERI, C. E.; DE CAMARGO, M. R.; FREGONESI, P. T. C. E.; DO CARMO, E. M.; NOZABIELLI, L. A. J. \& MARTINELLI, R. A. Stretch injuries of skeletal muscles: experimental study in rats' soleus muscle. Int. J. Morphol., 27(4):1139-1146, 2009.

SUMMARY: The study aimed to verify the physiological injury behavior by stretching the soleus muscle of rats, using a noninvasive experimental model. Twenty-four rats were used and divided into three groups of eight animals: control group (A), group that performed tetanus followed by electrical stimulation and a sudden dorsiflexion of the left paw performed by a device equipped with a mechanism of muscle soleus rapid stretching (B); and a group that only received the tetanus (C). Three days later, the animals were killed, and the soleus muscle was resected and divided into three segments. Morphological changes indicative of muscle damage appeared in all three segments of group B. In a lesser degree, similar changes were also detected in muscles subjected to only tetanus. This model was effective; reproducing an injury similar to what occurs in human sports injuries.

KEY WORDS: Disease models; Animal; Rats; Skeletal muscle; Tetany.

\section{INTRODUCTION}

Skeletal muscle lesions are a common phenomenon usually associated with intense physical motor activity either in humans or animals (Smith et al., 2001; Yu et al., 2002; 2003; Lapointe et al., 2004; Chen et al., 2007). It can be produced by various conditions that affect the muscle tissue, like myopathies, ischemia or inflammatory processes, or by trauma.

Stretch muscle lesions are probably the most frequent among sports traumas (Noonan et al., 1994; Butterfield et $a l ., 2008$ ) being usually indirectly produced by a powerful contraction combined with forceful lengthening which lead to an excessive effort or stress on the muscle (Rahusen $e t$ al., 2004; Butterfield \& Herzog, 2006; Tsuang et al., 2007; Brughelli \& Cronin, 2007).

Forced lengthening or eccentric contraction exercises may, and actually do, exceed the elastic capacity of the muscle tissue, thus producing stretch lesions at different levels depending on the traumatic agent type, intensity and duration (Harridge, 2007). Muscle stretch lesions are characterized by sarcolemma or more resistant membrane rupture (endomysium, perimysium, epimysium and basal membrane) responsible to muscle fiber structure maintenance, as observed in humans and animals (Stauber et al., 1988; Smith et al.; Yu et al., 2002; 2003; Koh et al., 2003; Lovering \& De Deyne, 2004; Takekura et al., 2007). The damaged muscle fibers undergo partial or complete segmentary necrosis and the necrotic tissue is phagocytized by macrophages, monocytes and phagocytes, which migrate into the fibers. Following this, the reparative process begins with the satellite cells migration into the lesion site and their differentiation in myoblasts, accompanied by intense ribosomal activity and protein synthesis to replace the sarcoplasm and the myofibrils (Harridge; Kuang \& Rudnicki, 2008).

\footnotetext{
* Departament of Physical Therapy, Presidente Prudente School of Sciences and Technology, São Paulo State University, Brazil.

**'Departament of Locomotion Apparatus' Biomechanics, Rehabilitation and Medicine, Ribeirão Preto School of Medicine, São Paulo University, Brazil.
} 
Most of the knowledge gathered on the pathologic findings and traumatic muscle lesions reparative process has resulted from experimental studies. Many different experimental models have been developed to produce muscle lesions, using intensive exercises (Lapointe et al., 2004; Lovering \& De Deyne; Thabet et al., 2005; Widrick \& Barker, 2006; Takekura et al.) or stretching as mechanism by which lesion were produced. Stretch lesions can be produced either by a single slow forceful movement (Garrett et al., 1987; Reddy et al., 1993; Taylor, 1993; Tidball et al., 1993; Noonan et al.; Rahusen et al.; Butterfield et al.) or by repetitive or cyclic motion (McCully \& Faulkner, 1985 and 1986; Fritz \& Stauber, 1988; Stauber et al.; Lieber \& Fridén, 1993; Koh et al.). The rabbit seems to be the animal model most frequently used for the experiments (Stauber et al.; Noonan et al.; Butterfield et al.) but also mice, rats and frogs have been used (McCully \& Faulkner, 1985; Stauber et al.; Koh et al.).

Despite the considerable number of studies on stretch muscle lesions, this traumatic entity is not completely elucidated, thus requiring more investigation which may contribute to improve basic phenomena involved, understanding, and to become prevention and treatment effectiveness. Most of stretch muscle lesion clinical cases are characterized by incomplete fiber rupture following an active stretching in which a muscle strongly contracted against resistance. However, experimental studies were aimed on passively or actively produced complete fiber rupture. The objective this investigation was to study muscle fiber lesion site and degree in an adult rats' experimental model of soleus muscle moderate stretching of rats submitted to tetanus by direct percutaneous electrical stimulation followed by sudden resistance application.

\section{MATERIAL AND METHOD}

Twenty-four male Wistar rats weighing $245 \mathrm{~g}$ on average (range: $236-254 \mathrm{~g}$ ) were used. Animals were maintained under adequate sanitary conditions in groups of three or four inside plastic cages and fed rat chow and water ad libitum. Before beginning the experiment with the animals, a device basically consisting of a spring trigger mechanism and able to suddenly stretch the rat's soleus muscle, was specially designed, built and tested. It was calibrated to deliver $2.25 \mathrm{~J}$ $(225 \mathrm{kgf} / \mathrm{mm})$ at each stroke (Fig. 1).

Following identification, the animals were anesthetized with an intraperitoneal sodium pentobarbital injection (Nembutal, Abbott, $0.5 \mathrm{mg} / 100 \mathrm{~g}$ body weight). Two electrodes were percutaneously introduced into the soleus muscle, with the positive pole (anode) being located near its origin in the popliteal fossa and the negative pole (cathode) near the Achilles tendon. Electrodes were connected to a surgical electrical stimulator, of routine use in brachial plexus and peripheral nerve exploration. Soleus muscle tetanus was then produced with a cyclic stimulation of increasing frequency up to a maximum of $25 \mathrm{~Hz}$, at which point the

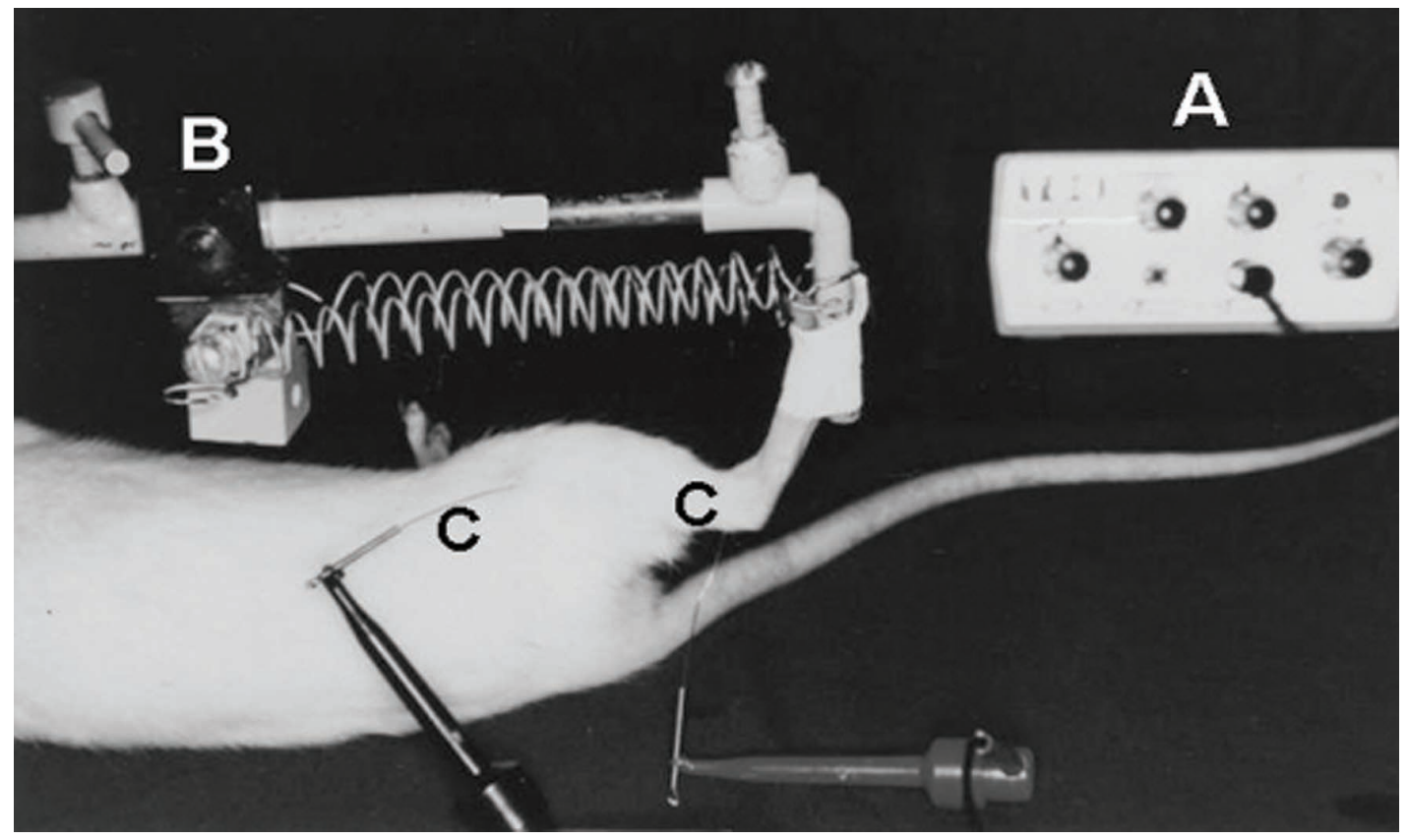

Fig. 1 Experimental set-up with the electrical stimulator (A), the anesthetized rat fixed to the table with the right hind paw attached to stretching device (B) and the percutaneous electrodes $(\mathrm{C})$ in place. The tetanized soleus muscle is ready for stretching. 
muscle appeared to be paralyzed with the foot in complete extension. The muscle was then submitted to a single sudden stretching, the stimulation being discontinued immediately thereafter (Fig. 2).

Soleus muscle was then left to rest for 30 seconds and the procedure was repeated. Ten repetitions were made, the animal being then taken back to its cage to recover from the anesthesia immediately thereafter. The total energy delivered in each experiment was 22.5 Joules $(2250 \mathrm{kgf} / \mathrm{mm})$. Rats were divided into three groups according to the type of procedure carried out, as follows: Intact animals, for control $(\mathrm{n}=8)$; Stretching following soleus muscle tetanus $(\mathrm{n}=8)$; Soleus muscle tetanus $(\mathrm{n}=8)$.

The animals were killed three days after the experiment by ethyl ether inhalation and the entire soleus muscle was removed with both the proximal and distal tendons, divided into three segments (proximal, middle and distal) of approximately the same length, sprinkled with talcum, fixed onto a metal plate with gum, immersed in liquid nitrogen for 45 seconds to freeze and stored in individual plastic containers at $-80^{\circ} \mathrm{C}$. Three days later, each segment was processed for histologic examination. Serial $8 \mathrm{~mm}$-thick histologic sections were obtained from each muscle segment with a cryostat microtome at $-15^{\circ} \mathrm{C}$ and stained with toluidine blue or with the histochemical method for the acid phosphatase enzymatic reaction. In the first case, the sections were mounted onto plates and covered with a glass platelet in the usual way; in the second case, they were mounted between glass platelets.

The sections thus obtained and stained were examined under a light microscope at $250 \mathrm{X}$ and $400 \mathrm{X}$ magnifications aiming qualitative and quantitative analysis. Sections stained with toluidine blue were particularly inspected for acute lesion any sign (homogeneous ground grass appearance due to diffuse myofibril destruction, diffuse basophilia produced by ribosomal concentration and centralized nuclei), reparative process (heterogeneous myofibril distribution due to scattered phagocytosis, peripheral basophilia due to peripheral ribosomal concentration and centralized nuclei), or chronic lesion (fragmented myofibrils, centralized nuclei, acute lesion signs absence) (Lapointe et al.; Järvinen et al., 2005).

In the histochemical study, the parameter investigated was abnormal lysosomal activity, indicating phagocytosis. Considering that such an activity does not exist in normal muscle fibers, this is the most reliable criterion to characterize acute fiber lesion (Järvinen et al.). In addition to the specific

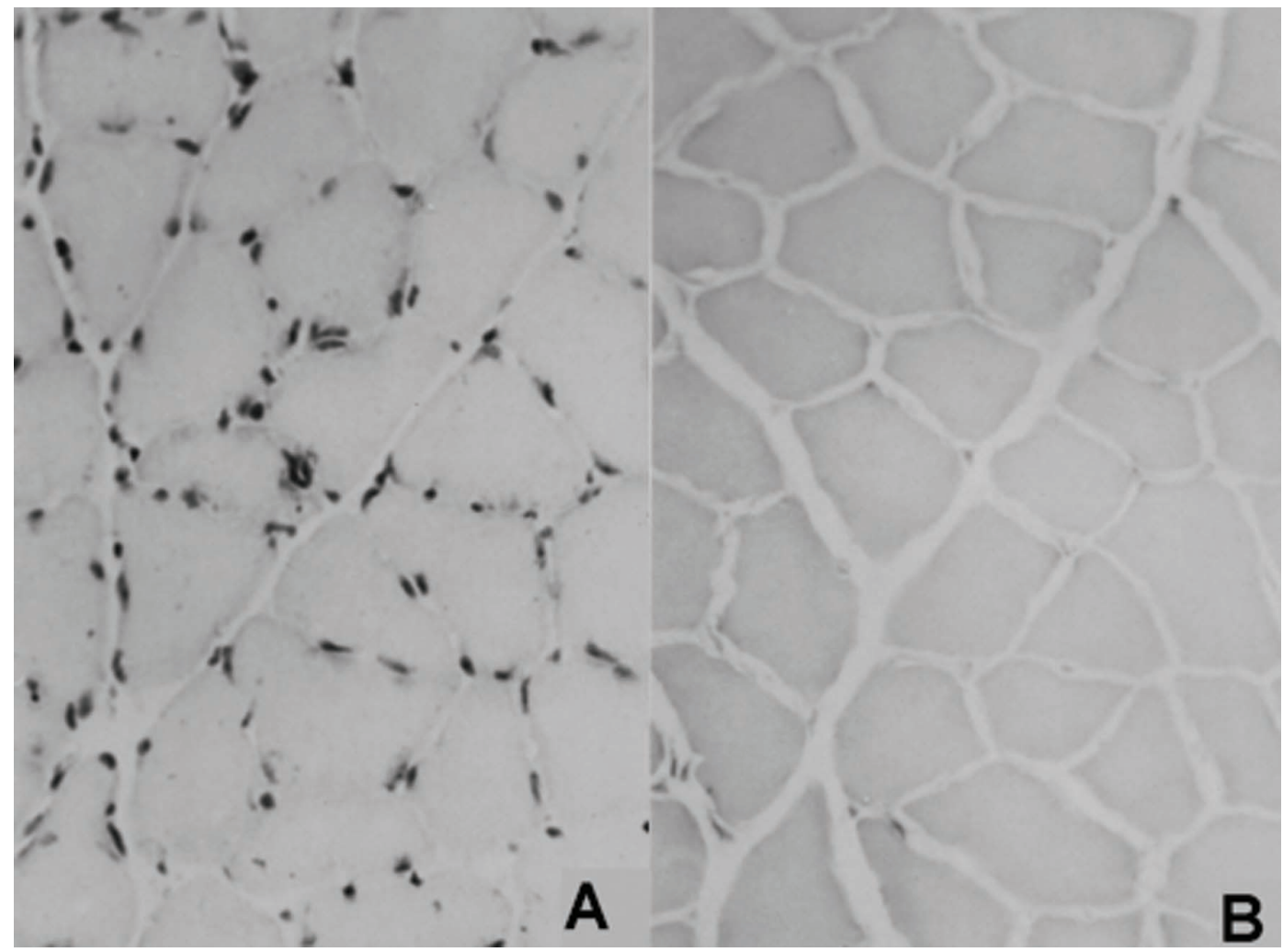

Fig. 2 Control group. Transverse sections of intact soleus muscle stained with toluidine blue (A, 400X) and acid phosphatase enzymatic reaction $(\mathrm{B}, 400 \mathrm{X})$ showing the typical ground glass appearance of normal muscle fibers, regular fiber distribuition, very similar fiber diameters and eccentric nuclei. 
muscle fiber lesion and regeneration parameters, phagocyte and macrophage invasion, typical from the early lesion stages, and satellite cell migration, characteristic from the reparative process, were also searched for.

The damaged and regenerating muscle fibers were counted in relation to the total muscle fibers number in each analyzed field and data were submitted to statistical analysis by the Kruskal-Wallis nonparametric test and multiple comparison test at the $5 \%$ level of significance $(\mathrm{p} \leq 0.05)$.

The study execution attained to parameters proposed by a Federal Law on Animal Experimentation: "Princípios Éticos na Experimentação Animal do Colégio Brasileiro de Experimentação Animal", Federal Law n 6.638, of 1979. The procedures used are scientifically necessary and that the minimum possible pain or stress has been imposed on the animals.

\section{RESULTS}

Both anesthetic and surgical procedures were well tolerated by all animals but one. All were able to walk a few hours after the procedure and resumed apparently normal gait within two or three clays. No significant weight loss was observed in any group $(\mathrm{p}>0.05)$ at any time.
Histologic and histochemical observations. Muscle fibers were entirely normal in group 1, with most of the sections displaying the typical ground glass appearance, regular fiber distribution, very similar fiber diameters and eccentric nuclei (Figure 2-A and 2-B).

Damaged and regenerating fibers were observed in all animals from group 2 (stretching following tetanus of the soleus muscle). In the toluidine-stained sections, damage and regeneration became evident by the presence of heterogeneous myofibril distribution (myofibril destruction and phagocytosis), peripheral basophilia (ribosome concentration) and centralized nuclei, in addition to a cell infiltrate varied degree (Figure 3-A). In the acid phosphatase enzymatic reaction, damage became evident by lysosome concentration, indicating phagocytosis of myofibrils (Fig. 3-B).

The same signs were observed to a much lesser extent in the animals of group 3, with the cell infiltrate exception, only observed in the soleus muscle proximal segment of a single animal (Figures 4-A and B).

Muscle fiber counts. Damaged and regenerating muscle fibers were counted in everyone by three segments of the soleus muscle in each group the lesion signs presented by fibers segments is shown 5, 6 and 7 figures. Each graphs displays average; standard deviation and range for

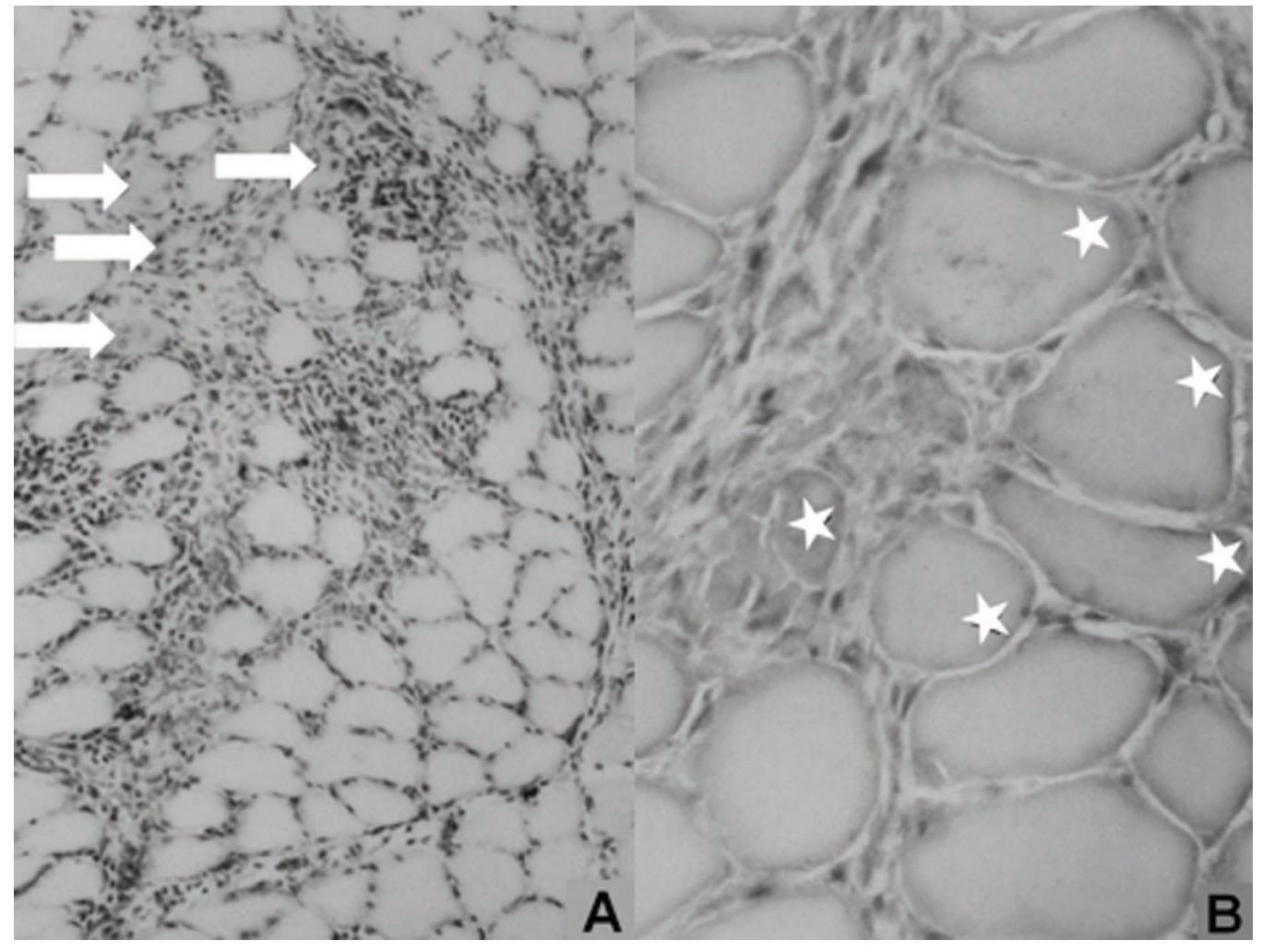

Figure 3 - Soleus muscle stretching following tetanus transverse sections stained with toluidine blue (A, 400X) and acid phosphatase enzymatic reaction (B, 400X) showing an intense cell infiltrate, fibers undergoing regeneration (A, arrows) and diffuse

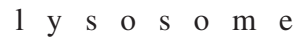
concentration $(\mathrm{B}, *)$. 


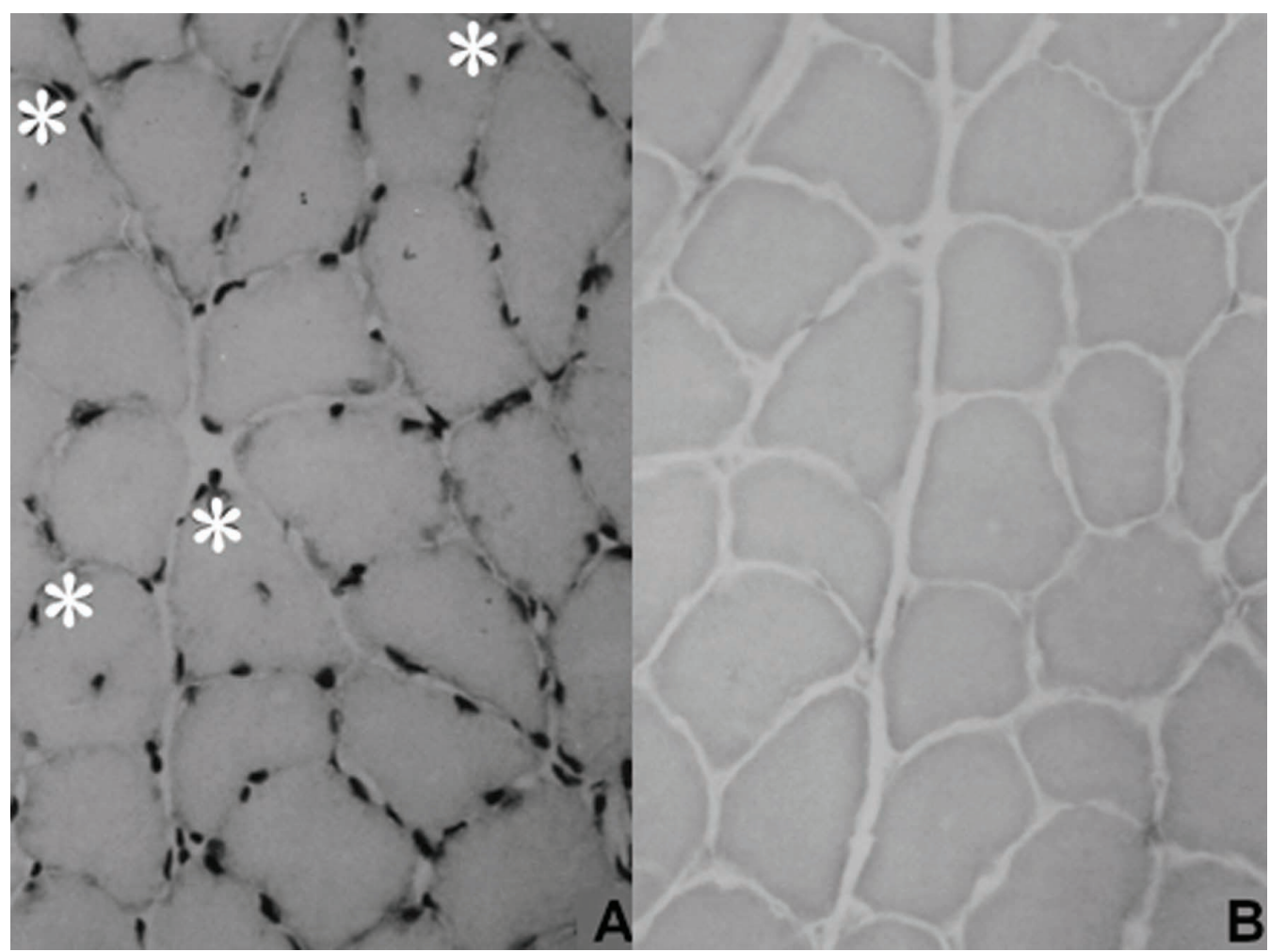

Fig. 4. Only soleus muscle stretching transverse sections stained with toluidine blue (A, 400X) and acid phosphatase enzymatic reaction $(\mathrm{B}$, 400X) showing nearly normal appearance but centralized nuclei $(\mathrm{A}, *)$ and slight peripheral lysosome concentration (B).

proximal, middle and distal segments in groups 1, 2 and 3 respectively. Considering the entire soleus muscle, the total average number of damaged fibers was 26.2 in group 1, 136.35 in group 2 and 72.87 in group 3.

Statistical analysis showed that the differences between group 1 and groups 2 and 3 were significant $(\mathrm{p}<0.05)$, in both segmental and total counts.

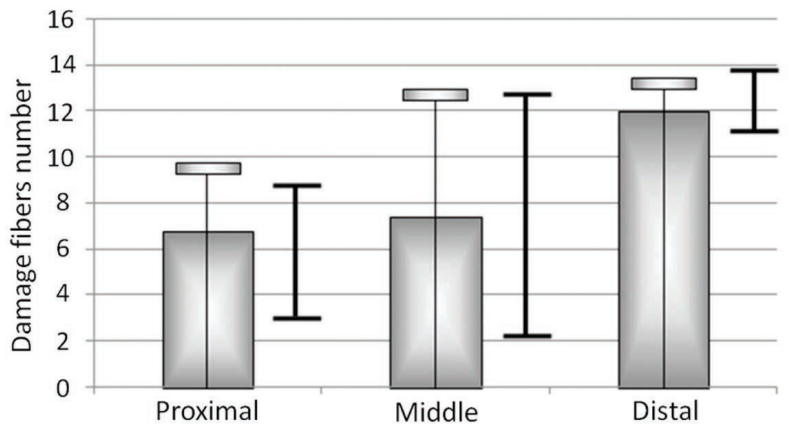

Fig. 5. Control group (1) rats' soleus muscle damage fibers average (gray bar); standard deviation (gray cross-bar) and range (black line) to each segment.

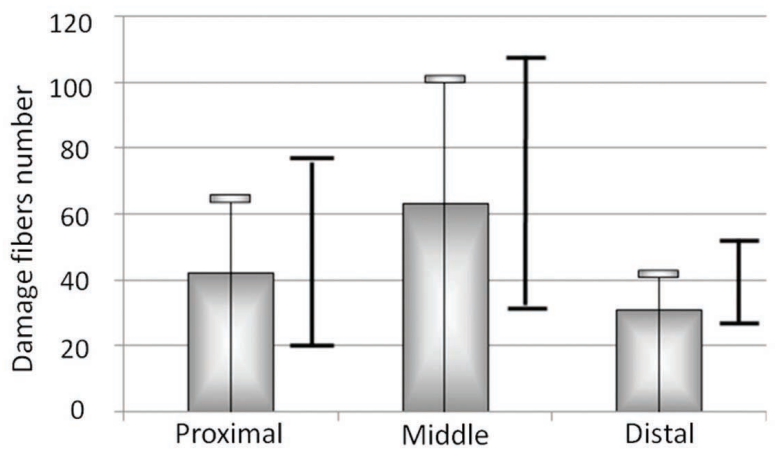

Fig. 6. Stretching following muscle tetanus group (2) rats' soleus muscle damage fibers average (gray bar); standard deviation (gray cross-bar) and range (black line) to each segment.

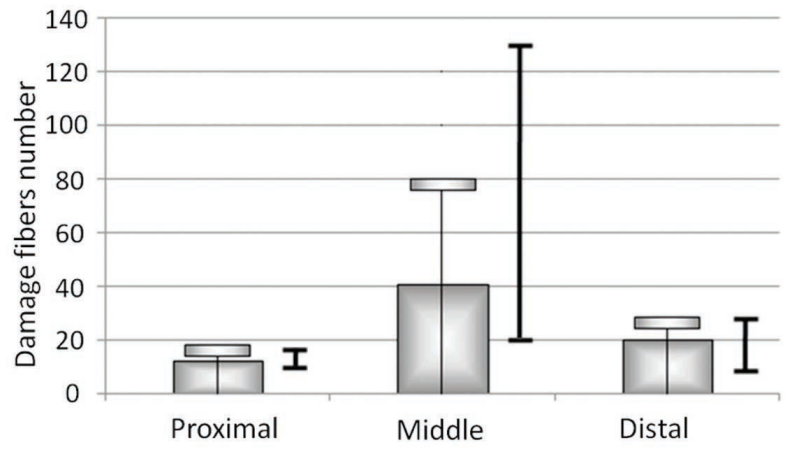

Fig. 7. Muscle tetanus group (2) rats' soleus muscle damage fibers average (gray bar); standard deviation (gray cross-bar) and range (black line) to each segment. 


\section{DISCUSSION}

It is well known that sports in general impose a high muscle lesions incidence on athletes, mainly due to stretching, and many aspects of these lesions still remain obscure (Thabet et al.; Butterfield \& Herzog; Brughelli \& Cronin; Tsuang et $a l ., 2007)$. On the other hand, stretch lesions in humans' studies are very difficult for obvious reasons, particularly the need for a biopsy, refused by most patients. Therefore, the muscle lesion reliable experimental model development by stretching is desirable and has been attempted in animals. Most of the models proposed use passive stretching of a relaxed muscle till complete rupture occurs, whilst in humans great part of lesions are produced by one or more sudden active muscle contractions against strong resistance or one or more sudden lengthening of an actively contracted muscle, which do not result in total tissue separation or rupture. Taking into consideration the differences between actual lesion mechanism and that used in most of the experimental studies, it was our purpose to develop a more accurate muscle lesion model by stretching during a strong contraction in rats' soleus muscle. This would be obtained by submitting the muscle to a high frequency, low voltage direct percutaneous electrical stimulation till tetanus became evident. The rats' soleus muscle presents a fusiform structure, its fibers having approximately the same length and extending from one end of the muscle to the other, so that most of them can be analyzed in a single transverse section at its middle portion (Williams \& Goldspink, 1973).

Histologic studies were programmed to be carried out on the third day, a time when the histologic changes are more evident and can be evaluated both qualitatively and quantitatively (McCully \& Faulkner, 1985; 1986; Stauber et $a l$.). This also occurs in humans, whose stretched muscles present alternate normal fibers areas, fiber necrosis and an anarchic reparative process a few days after injury. The reparative process intensifies after the third day so that the differences between normal and damaged muscle fibers become conspicuous after this period (Smith et al.; Yu et al., 2002; Thabet et al., 2005). Our results showed that acute lesion signs, like fiber necrosis, cell infiltrate and basophilia, were associated with chronic lesion signs, like centralized nuclei, as early as on the third day, as also demonstrated before (McCully \& Faulkner, 1985 e 1986; Stauber et al.). Another presented study interesting finding was that damage fiber number varied between different same muscle segments, same groups different animals group and different groups, and this probably means that susceptibility to lesion differs among animals of the same species, as also suggested by other authors (McCully \& Faulkner, 1985; 1986; Stauber et al.).

As expected, the damage muscle fibers number was significantly higher in group 2 (stretching following soleus muscle tetanus) compared to group 1 (intact animals), considering the three regions studied. Compared to group 3 (tetanus of the soleus muscle only), the damage fibers number group 2 was significantly higher only at muscle proximal third; on middle and distal thirds, although present, the differences were not significant. A high number of damaged muscle fibers were also identified in group 3 compared to normal controls. Although the differences were significant only at muscle middle and distal thirds that indicates that tetanus can produce muscle fiber lesion on its own.

Another interesting finding was that, in many instances, damaged fibers groups were found to be surrounded by normal appearing fibers, thus characterizing heterogeneity and segmentary lesion distribution along the muscle, its indicate that the stretching tension applied did not distribute evenly along the muscle. In other words, tension tends to concentrate at different sites along the muscle at the same time and wherever it concentrates damage occurs. To a certain extent, fiber damage occurrence along the three muscle segments contradicts the conclusion that muscle lesion tends to occur near or at the myotendinous junction (Garrett et al.; Reddy et al.; Brughelli \& Cronin) or muscle belly (Lieber \& Fridén; Stauber et al., 1988; Tidball et al., 1993). With respect to the muscle activation state, there are indications that damage occurs both at muscle belly with its relaxation and at myotendinous junction with its contraction. The damage always can happen near the myotendinous junction (Garrett et al.) or at muscle belly (Fritz \& Stauber; Stauber et al.), regardless of the activation state, so that this is still a contradictory matter.

In addition to the site, the lesion intensity observed in the present study also differed from other authors' data. Very severe muscle lesion was observed a study which 50 slow stretching movements (5 sets of 10 ) were applied to rats' soleus muscle also submitted to tetanus. The most striking finding being the large number of damaged fibers and the intense mononuclear cell infiltrate 23 . The less intense infiltrate and the lower damage fibers number observed in our study can be explained by stretching movements smaller number (Fritz \& Stauber) applied to the muscle. Both necrosis and cell infiltrate were found in all three segments of the muscle, confirming that the muscle is liable to suffer focal damage along its entire length. However, the fact that this finding was more evident in the proximal third probably means that this is the most susceptible region, although damage fiber number was higher in the middle third.

In conclusion, the skeletal muscle stretch lesion model studied here is efficient and can be reproduced. Damage type produced has a focal or segmentary distribution along the entire muscle length and not too severe in character, due to the relatively small number of stretching movements applied. 
PACHIONI, S. C. A.; MAZZER, N.; BARBIERI, C. E.; DE CAMARGO, M. R.; FREGONESI, P. T. C. E.; DO CARMO, E. M.; NOZABIELLI, L. A. J. \& MARTINELLI, R. A. Lesión por estiramiento de los músculos esqueléticos: estudio experimental con el músculo soleus de ratas. Int. J. Morphol., 27(4):1139-1146, 2009.

RESUMEN: El estudio tuvo como objetivo verificar el comportamiento fisiológico de la lesión por estiramiento de los músculos soleos de ratas, utilizando un modelo experimental no invasivo. Veinticuatro ratas se utilizaron y se dividieron en tres grupos de ocho animales: Grupo A control; Grupo B se realiza tetanización por la estimulación eléctrica seguida de una repentina flexión dorsal de la pierna izquierda, realizado por un dispositivo equipado con un mecanismo rápido de estiramiento del músculo sóleo y Grupo C los animales sólo recibieron la tetanización. Tres días después, los animales fueron sacrificados, el músculo sóleo fue resecado y dividido en tres segmentos. Cambios morfológicos indicativos de daño muscular aparecieron en los tres segmentos del grupo B. En menor grado, cambios similares se detectaron en los músculos sometidos solamente al tetanización. El modelo fue eficaz, la reproducción de la lesión fue similar a lo que ocurre en las lesiones deportivas humanas.

PALABRAS CLAVE: Modelos de enfermedad; Músculo esquelético; Ratas; Tetania.

\section{REFERENCES}

Brughelli, M. \& Cronin, J. Altering the length-tension relationship with eccentric exercise: implications for performance and injury. Sports Med., 37(9):807-26, 2007.

Butterfield, T. A. \& Herzog, W. Effect of altering length and activation timing of muscle on fiber strain and muscle damage. J. Appl. Physiol., 100:1489-98, 2006.

Butterfield, T. A.; Zhao, Y. \& Agarwal, S. Cyclic compressive loading facilitates recovery after eccentric exercise. Med. Sci. Sports Exerc., 40(7):1289-96, 2008.

Chen, W.; Ruell, P. A.; Ghoddusi, M.; Kee, A.; Hardeman, E. C.; Hoffman, K. M. \& Thompson, M. W. Ultrastructural changes and sarcoplasmic reticulum $\mathrm{Ca} 2+$ regulation in red vastus muscle following eccentric exercise in the rat. Exp. Physiol., 92:437-47, 2007.

Fritz, V. K. \& Stauber, W. J. Characterization of muscles injured by forced lengthening. II. Proteoglycans. Med. Sci. Sports Exerc., 20(4):354-61, 1988.

Garrett, W. E. Jr.; Safran, M. R.; Seaber, A. V.; Glisson, R. R. \& Ribbeck, B. M. Biomechanical comparison of stimulated and nonstimulated skeletal muscle pulled to failure. Am. J. Sports Med., 15(5):448-54, 1987.

Harridge, S. D. Plasticity of human skeletal muscle: gene expression to in vivo function. Exp. Physiol., 92(5):78397, 2007.

Järvinen, T. A. H.; Järvinen, T. L.; Kääriäinen, M.; Kalimo, H. \& Järvinen, M. Muscle injuries: biology and treatment. Am. J. Sports Med., 33(5):745-64, 2005.
Koh, T. J.; Peterson, J. M.; Pizza, F. X. \& Brook, S. V. Passive stretches protect skeletal muscle of adult and old mice from lengthening contraction-induced injury. J. Gerontol. A Biol. Sci. Med. Sci., 58B(7):592-7, 2003.

Kuang, S. \& Rudnicki, M. A. The emerging biology of satellite cells and their therapeutic potential. Trends Mol. Med., 14(2):82-91, 2008.

Lapointe, B. M.; Frenette, J. \& Côté, C. H. Lengthening contraction-induced inflammation is linked to secondary damage but devoid of neutrophil invasion. J. Appl. Physiol., 92(5):1995-2004, 2002.

Lieber, R. L. \& Fridén, J. Muscle damage is not a function of muscle force but active muscle strain. J. Appl. Physiol., 74(2):520-6, 1993.

Lovering, R. M. \& De Deyne, P. G. Contractile function, sarcolemma integrity, and the loss of dystrophin after skeletal muscle eccentric contraction-induced injury. Am. J. Physiol. Cell. Physiol., 286(2):C230-8, 2004.

McCully, K. K. \& Faulkner, J. A. Characteristics of lengthening contractions associated with injury to skeletal muscle fibers. J. Appl. Physiol., 61(1):293-9, 1986.

McCully, K. K. \& Faulkner, J. A. Injury to skeletal muscle fibers of mice following lengthening contractions. $J$. Appl. Physiol., 59(1):119-26, 1985.

Noonan, T. J.; Best, T. M.; Seaber, A. V.; Garrett Jr, W. E. Identification of a threshold for skeletal muscle injury. Am. J. Sports Med., 22(2):257-61, 1994. 
PACHIONI, S. C. A.; MAZZER, N.; BARBIERI, C. E.; DE CAMARGO, M. R.; FREGONESI, P. T. C. E.; DO CARMO, E. M.; NOZABIELLI, L. A. J. \& MARTINELLI, R. A. Stretch injuries of skeletal muscles: experimental study in rats' soleus muscle. Int. J. Morphol., 27(4):1139-1146, 2009.

Rahusen, F. T. G.; Weinhold, P. S. \& Almekinders, L. C. Nonsteroidal anti-inflammatorory drugs and acetaminophen in the treatment of an acute muscle injury. Am. J. Sports Med., 32(8):1856-9, 2004.

Reddy, A. S.; Reedy, M. K., Best, T. M.; Seaber, A. V. \& Garrett Jr, W. E. Restriction of the injury response following an acute muscle strain. Med. Sci. Sports Exerc., 25(3):321-7, 1993.

Smith, H. K.; Maxwell, L.; Rodgers, C. D.; McKee, N. H. \& Plyley, M. J. Exercise-enhanced satellite cell proliferation and new myonuclear accretion in rat skeletal muscle. $J$. Appl. Physiol., 90(4):1407-14, 2001.

Stauber, W. T.; Fritz, V. K.; Vogelbach, D. W. \& Dahlmann, B. Characterization of muscles injured by forced lengthening. I. Cellular infiltrates. Med. Sci. Sports Exerc., 20(4):345-53, 1988.

Takekura, H.; Fujinami, N.; Nishizawa, T.; Ogasawara, H. \& Kasuga, N. Eccentric exercise-induced morphology changes in the membrane systems involved in excitationcontraction coupling in rat skeletal muscle. J. Physiol., 533:571-83, 2001.

Taylor, D. C.; Dalton, J. D.; Seaber, A. V. \& Garrett Jr, W. E. Experimental muscle strain injury. Early functional and structural defects and the increased risk for reinjury. Am. J. Sports Med., 21(2):190-4, 1993.

Thabet, M.; Miki, T.; Seino, S. \& Renaud, J. M. Treadmill running causes significant fiber damage in skeletal muscle of KATP channel-deficient mice. Physiol. Genomics, 22(2):204-12, 2005.

Tidball, J. G.; Salem, G. \& Zernicke, R. Site and mechanical conditions for failure of skeletal muscle in experimental strain injuries. J. Appl. Physiol., 74(3):1280-6, 1993.

Tsuang, Y. H.; Lam, S. L.; Wu, L. C.; Chiang, C. J.; Chen, L. T.; Chen, P. Y.; Sun, J. S. \& Wang, C. C. Isokinetic eccentric exercise can induce skeletal muscle injury within the physiologic excursion of muscle-tendon unit: a rabbit model. J. Orthop. Surg., 2:13-9, 2007.

Widrick, J. J. \& Barker, T. Peak power of muscles injured by lengthening contractions. Muscle Nerve, 34(4):4707, 2006.

Williams, P. E. \& Goldspink. G. The effect of immobilization on the longitudinal growth of striated muscle fibers. $J$. Anat., 116(Pt.1):45-55, 1973.
Yu, J. G.; Fürst, D. O. \& Thornell, L. E. The mode of myofibril remodeling in human skeletal muscle affected by DOMS induced by eccentric contractions. Histochem. Cell. Biol., 119(5):383-93, 2003.

Yu, J. G.; Malm, C. \& Thornell, L. E. Eccentric contractions leading to DOMS do not cause loss of desmin nor fibre necrosis in human muscle. Histochem. Cell. Biol., 118(1):29-34, 2002.

Correspondence to:

Célia Aparecida Stellutti Pachioni

Departament of Physical Therapy,

Presidente Prudente School of Sciences and Technology,

São Paulo State University, Brazil.

Rua Roberto Simonsen n 305

CEP: $19060-900$

Presidente Prudente,

São Paulo, BRAZIL.

Phone: +55 +18 32295365 Ext: 213

Received: 17-07-2009

Accepted: 10-10-2009 